emphasized the importance of paying due consideration to the views of other countries in the Commonwealth. $\mathrm{He}$ thought, on the grounds of efficiency, however, that there was much to be said for one office.

With the creation of an integrated diplomatic service, the main recommendations of the Plowden Committee had already been put into effect. Since January 1, 1965 , eighty-eight members of the former Foreign Service had been posted to posts in the Commonwealth Relations Office and forty-two members of the Commonwealth Relations Office had been posted to Foreign Offico posts.
The communications system and the cyphers had been unified, as had the information services of the two offices, and significant progress had been made in the making and implementation of policy, but he could not give Lord Gladwyn any assurance that the two offices would be merged within the next year. The Government was in fact working towards an organization in which, whether or not there were two Departments of State, and two Secretaries of State, the co-operation between the two was such as to eliminate very largely the inefficiencies and illogicalities.

\title{
REFORM OF SCOTTISH UNIVERSITIES
}

$\mathrm{T}$ HE Universities (Scotland) Bill received the Royal Assent on March 9. The Bill has as its purpose to implement some specific proposals of the Robbins Report for the development of higher education in Scotland. As Lord Hughes explained in moving the second reading in the House of Lords, its aim is to modernize the constitutions of four old Scottish universities and to pave the way for establishing a new university at Dundee. After looking at the constitutions of the existing universities, the Robbins Committee recommended that the four older Scottish universities should be free from the cumbersome outmoded procedures, under the Universities (Scotland) Acts, 1858 and 1889 , by which they still had to conduct academic and other business. This procedure involved consultations between the four universities, laying ordinances before Parliament, and approval of them by the Privy Council. This process could take anything from 6 months to a year, and extended into such business as the founding of new chairs and making rogulations for new degrces.

There is no controversy about the basic aim of the Bill to modernize the constitutions of these four old universities, although there had been a sharp difference of view on the means by which this should be achieved. The present university authorities asked only for certain minimum reforms to the existing acts, but the Association of University Teachers urged that no really satisfactory reforms could be achieved unless the universities revised their constitutions by drawing up charters.
Lord Hughes said that the Bill was essentially an enabling one, adjusting the balance of power within the Universities to give all the members of a university a due share in its government, and leaving it to the university to decide the rate and nature of constitutional reform. Part I empowered each of the four universities to contract out of the present legislation by petitioning for a Royal Charter whenever it judged the time to be right, provided that the views of all members of the university were canvassed before any such move was made.

In Part II, the essential minimum reforms to the present constitutions were made. By Clauses 2 and 7 the composition of the main organs of university government, the court and the senate, were revised, and non-professorial staff-readers and lecturers-were given a larger share in the management of the university. Clauses 4 and 6 swept away the outmoded and time-wasting procedures at present obtaining and replaced them by new procedures which distinguish between matters of public importance and academic and other business Iying properly within the discretion of the university.

Part III of the Bill took the legislative steps necessary to separate Queen's College, Dundee, from St. Andrew's University when the new University of Dundee came to be founded by Royal Charter. This part of the Bill is wholly non-controversial but somewhat complex and technical in character.

\section{LATITUDE-PERIOD DEPENDENCY OF GEOMAGNETIC MICROPULSATIONS}

\author{
By T. J. HERRON and DR. J. R. HEIRTZLER \\ Lamont Geological Observatory, Columbia University, Palisades, New York
}

$\mathrm{I}^{\mathrm{N}}$ $\mathbf{N}$ the analysis of geomagnetic micropulsations in the period range of ten to several hundred seconds, various authors have commented on the dependence of poriod on latitude. The nature of such a dependence, if one exists, has not been fully resolved. The subject is of importance to thoories of origin which attribute micropulsations to hydromagnetic oscillations in the magnetosphere. The study of poriod difference at latitudinally separated. stations has involved the direct comparison from analogue records of simultaneous micropulsations, the comparison of power spectra of simultaneous micropulsation wavetrains, and the comparison, over an interval of several months and at various latitudes, of the predominant periods of micropulsations that are not necessarily simultanoous. The conclusions reached have been varied. Voelker ${ }^{i}$ recorded micropulsations simultaneously with three similar instruments $\left(48 \cdot 9^{\circ}-54 \cdot 6^{\circ}\right.$ geomagnetic letitude) and reported a systematic increase of period with latitude for the $H$-component of $P c$-type oscillations and for the $H$-component of a damped pulsation named 'pulsation single effect'. Obayashi and Jacobs' compiled a statistical scatter diagram of period versus latitude from data of eleven observatories ( $28^{\circ}-67^{\circ}$ geomag. lat.) which, despite eonsiderable scatter, showed an increase of period with latitude. Duncan ${ }^{3}$ compared the predominant periods at three Australian stations $\left(29^{\circ}-52^{\circ}\right.$ geomag. lat.) and found an increase of period with latitude. Other investigators, however, havo not found such an effect. Ellis ${ }^{4}$, studying the data from the three Australian stations used by Duncan ${ }^{3}$, found no latitude-period dependence. Kornack et al.5 computed power spectra of magnetotelluric micropulsations at stations separated in latitude $\left(22^{\circ}-40^{\circ}\right.$ geomag. lat.) and reported little or no difference in the period.

To study the latitude-period dependeney, the Geomagnetism Group of Lamont Geological Observatory recorded micropulsation activity simultaneously at pairs of stations ranging from $36^{\circ}$ to $61^{\circ}$ geomagnetic latitude. Because the results of Obayashi and Jacobs ${ }^{2}$ indicated a much more rapid period increase near the auroral zones 